\title{
Effects of supplemental butyrate and weaning on rumen fermentation in Holstein calves
}

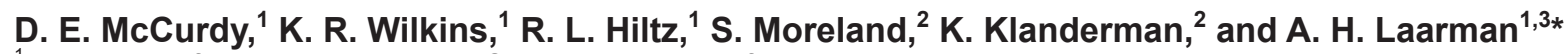 \\ ${ }^{1}$ Department of Animal and Veterinary Science, University of Idaho, Moscow 83844-2330 \\ ${ }^{2}$ Nutriad Inc., Hampshire, IL 60140 \\ ${ }^{3}$ Department of Animal, Food, and Nutritional Science, University of Alberta, Edmonton, Alberta, Canada T6G2P5
}

\section{ABSTRACT}

The objectives of this study were to determine the effects of the weaning transition and supplemental rumen-protected butyrate on subacute ruminal acidosis, feed intake, and growth parameters. Holstein bull calves $(\mathrm{n}=36 ;$ age $=10.7 \pm 4.1 \mathrm{~d} ; \pm$ standard deviation $)$ were assigned to 1 of 4 treatment groups: 2 preweaning groups, animals fed milk replacer only (PRE-M) and those fed milk replacer, calf starter, and hay (PRE-S); and 2 postweaning groups, animals fed milk replacer, calf starter, and hay without supplemental rumenprotected butyrate (POST-S) or with supplemental rumen-protected butyrate at a rate of $1 \% \mathrm{wt} / \mathrm{wt}$ during the 2-wk weaning transition (POST-B). Milk replacer was provided at $1,200 \mathrm{~g} / \mathrm{d}$; starter, water, and hay were provided ad libitum. Weaning took place over $14 \mathrm{~d}$ by reducing milk replacer provision to $900 \mathrm{~g} / \mathrm{d}$ in wk 7, 600 $\mathrm{g} / \mathrm{d}$ in wk 8 , and $0 \mathrm{~g} / \mathrm{d}$ in wk 9 . Rumen $\mathrm{pH}$ was measured continuously for $7 \mathrm{~d}$ during wk 6 for PRE-S and PRE-M and during wk 9 for POST-S and POST-B. After rumen $\mathrm{pH}$ was measured for $7 \mathrm{~d}$, calves were euthanized, and rumen fluid was sampled and analyzed for volatile fatty acid (VFA) profile. Individual feed intake was recorded daily, whereas, weekly, body weights were recorded, and blood samples were collected. Compared with PRE-M, PRE-S calves tended to have a greater total VFA concentration $(35.60 \pm 11.4$ vs. $11.90 \pm 11.8$ $\mathrm{m} M)$ but mean rumen $\mathrm{pH}$ was unaffected $(6.25 \pm 0.22$ vs. $6.17 \pm 0.21$, respectively). Between PRE-S (wk 6) and POST-S (wk 9), calf starter intake increased (250 \pm 219 vs. $2,239 \pm 219 \mathrm{~g} / \mathrm{d})$, total VFA concentrations increased $(35.6 \pm 11.4$ vs. $154.4 \pm 11.8 \mathrm{mM})$, but mean rumen $\mathrm{pH}$ was unaffected $(6.25 \pm 0.22$ vs. $6.40 \pm 0.22$, respectively). Compared with POST-S, POST-B calves had greater starter intake in wk 7, 8, and 9, but POST$\mathrm{B}$ tended to have lower total VFA concentration (131.0

Received March 19, 2019.

Accepted June 3, 2019.

*Corresponding author: anne.laarman@ualberta.ca \pm 11.8 vs. $154.4 \pm 11.8 \mathrm{mM})$ and lower mean ruminal $\mathrm{pH}(5.83 \pm 0.21$ vs. $6.40 \pm 0.22)$. In conclusion, the weaning transition does not appear to affect rumen $\mathrm{pH}$ and VFA profile, but supplementing rumen-protected butyrate during the weaning transition increased starter intake and average daily gain. Further, these data suggest that the ability of the rumen to manage rumen $\mathrm{pH}$ changes fundamentally postweaning. Why weaned calves with lower rumen $\mathrm{pH}$ can achieve higher calf starter intakes is unclear; these data suggest the effect of rumen $\mathrm{pH}$ on feed intake differs between calves and cows.

Key words: butyrate, rumen $\mathrm{pH}$, dairy calf, weaning

\section{INTRODUCTION}

A smooth transition from a milk-based diet to solid feed is essential for maintaining intake, BW, and mitigating stress at weaning (Quigley et al., 1991; Weary et al., 2009; Sweeney et al., 2010). In newborn calves, the rumen is underdeveloped and physiologically nonfunctional, leaving calves reliant on a milk-based diet (Khan et al., 2011b). Ensuring sufficient rumen development before the weaning process is important to ensure BW gains do not decrease (Sweeney et al., 2010). Rumen development is driven by consumption of calf starter, which contains high content of rapidly fermentable carbohydrates, leading to elevated butyrate production (Bergman, 1990; Drackley, 2008) and decreased rumen $\mathrm{pH}$ (Khan et al., 2011b). Depressed rumen $\mathrm{pH}$ can lead to epithelial inflammation and compromise rumen health (Plaizier et al., 2008), highlighting the importance of tracking rumen $\mathrm{pH}$ and rumen development in the young calf.

Improving rumen development before weaning may be aided by supplemental butyrate (Connor et al., 2013; Khan et al., 2016). When rumen-protected butyrate was supplemented in milk replacer or calf starter before weaning, calves experienced increased ADG, BW, ruminal papillae length, and ruminal papillae width (Gorka et al., 2009, 2011). In lactating cows, un- 
protected butyrate improves ruminal papillae density, ruminal epithelium integrity, and VFA transport capacity (Laarman et al., 2013a,b; Govil et al., 2017). In all, exogenous butyrate appears to have positive effects on rumen development, whether rumen-protected or not. Whether exogenous butyrate should be supplemented continuously or only during diet transitions is unclear.

To our knowledge, the effect of weaning on rumen $\mathrm{pH}$ dynamics and starter supplementation with rumenprotected butyrate during the weaning transition has not yet been investigated. The objective of this study was to determine the effect of weaning and supplemental rumen-protected butyrate on ruminal acidosis, starter intake, and growth parameters in young calves. We hypothesized that increased calf starter during the weaning transition would depress rumen $\mathrm{pH}$ and that supplemental rumen-protected butyrate would help increase calf starter intake.

\section{MATERIALS AND METHODS}

All animal procedures were approved by the Institutional Animal Care and Use Committee at the University of Idaho (AUP \# 2016-32). All calves were treated with $0.90 \mathrm{mg}$ of ampicillin $/ \mathrm{kg}$ of BW upon arrival for $3 \mathrm{~d}$ at the recommendation of the attending veterinarian. Calves showing any reduced intake, dehydration, or scours were offered electrolytes (RE-SORB, Zoetis Services LLC, Parsippany, NJ) twice daily in addition to their milk replacer allotment.

\section{Animals and Treatments}

Holstein bull calves $(\mathrm{n}=36)$ sourced from a single commercial farm were fed $4 \mathrm{~L}$ of colostrum at birth and were transported to the Palouse Research, Extension, and Education Center over a 2-wk period. At arrival, calves were either $5 \mathrm{~d}(\mathrm{n}=12), 10 \mathrm{~d}(\mathrm{n}=12)$, or 16 $\mathrm{d}(\mathrm{n}=12)$ of age and were equally distributed among treatments by age. All calves were individually housed on sand with ad libitum access to water. All calves were fed milk replacer at 1,200 g/d of $(28 \% \mathrm{CP}, 18 \%$ fat; Calva Advantage, Calva Products LLC, Acampo, $\mathrm{CA})$ at 0630 and $1700 \mathrm{~h}$, until 6 wk of age. Any refusal of milk replacer greater than $400 \mathrm{~g} / \mathrm{d}$ over the course of the day was fed through esophageal tubing. A 2-wk weaning transition began in wk 7 and calves were completely weaned by the end of wk 8 . At the start of wk 7 , milk replacer allotment was reduced to $900 \mathrm{~g} / \mathrm{d}$; at the start of wk 8, milk replacer allotment was reduced to $600 \mathrm{~g} / \mathrm{d}$. Milk replacer feeding was completely removed at the start of wk 9, at which point calves were postweaning.
At $16 \mathrm{~d}$ of age, calves were allocated to 1 of 4 treatment groups: 2 preweaning groups, with animals fed either milk replacer only (PRE-M), or milk replacer, hay, and starter (PRE-S), and slaughtered at $6 \mathrm{wk}$ of age; and 2 postweaning groups, with animals fed milk replacer, hay, and starter either without supplemental rumen-protected butyrate (POST-S) or with supplemental rumen-protected butyrate (Ultramix-C, Nutriad, Hampshire, IL) at a rate of $1 \% \mathrm{wt} / \mathrm{wt}$ (weight of butyrate/weight of starter) during the 2-wk weaning transition (POST-B). For the POST-B calves, butyrate was mixed with the starter during the 2 wk weaning transition. After the weaning transition, POST-B calves were fed nonsupplemented starter for $1 \mathrm{wk}$ (until harvest). Starter (22.1\% CP, 36.5\% starch; AMPLICALF Starter 20, Land O'Lakes LLC, Tulare, CA) and medium chopped alfalfa hay $(19.8 \% \mathrm{CP}, 42.2 \% \mathrm{NDF})$ were fed daily at $0700 \mathrm{~h}$.

Intakes of grain, forage, and milk replacer were recorded daily. Body weights were recorded weekly and a jugular blood sample was collected. Blood was centrifuged at $3,000 \times g$ for $20 \mathrm{~min}$ at $4^{\circ} \mathrm{C}$, and plasma was aliquoted and frozen at $-20^{\circ} \mathrm{C}$ for metabolite analysis. Calves were given a calibrated ruminal pH logger (Dascor Inc., Escondido, CA) during wk 6 (PRE-M and PRE-S) or wk 9 (POST-S or POST-B), which recorded the ruminal $\mathrm{pH}$ every $2 \mathrm{~min}$ for $7 \mathrm{~d}$. After $7 \mathrm{~d}$, calves were euthanized by captive bolt and exsanguination; blood was then collected from the jugular/arterial flow and the rumen $\mathrm{pH}$ logger was retrieved and recalibrated to correct for drift. Rumen fluid samples were collected from the rumen through 4 layers of cheesecloth and snap-frozen in liquid nitrogen for VFA analysis.

\section{Sample Analysis}

Blood plasma was analyzed for glucose and BHB using commercial kits (Wako Diagnostics Inc., Mountain View, CA) and measuring absorbance on a commercial spectrophotometer (Molecular Devices LLC, San Jose, $\mathrm{CA}$ ). Rumen $\mathrm{pH}$ was analyzed for minimum, mean, and maximum $\mathrm{pH}$, duration of ruminal $\mathrm{pH}$ less than 5.8, and area under the curve of ruminal pH less than 5.8. For VFA analysis, rumen fluid was acidified with $25 \%$ meta-phosphoric acid, centrifuged at 24,750 $\times g$ for 20 min at $4^{\circ} \mathrm{C}$. The supernatant was frozen at $-20^{\circ} \mathrm{C}$ for $12 \mathrm{~h}$, thawed, and then centrifuged at 13,000 $\times \mathrm{g}$ for 10 min at $4^{\circ} \mathrm{C}$. The supernatant was then analyzed on an Agilent 6890 series gas chromatographer with a 7673 series injector (Agilent, Wilmington, DE), with a DBFFAP column using hexane and acetone solvents and 2-ethylbutyric acid 99\%, as previously described (Hall et al., 2018). 


\section{Statistical Analysis}

Recorded BW were used to determine ADG using PROC REG in SAS (SAS 9.4, SAS Institute Inc., Cary, NC). Data on nutrient intake and blood metabolites were analyzed using the MIXED procedure of SAS (SAS 9.4) for a randomized complete block design according to the following model:

$$
\mathrm{Y}=\mu+\mathrm{t}_{\mathrm{i}}+\mathrm{w}_{\mathrm{j}}+\mathrm{t} \times \mathrm{w}_{\mathrm{ij}}+\varepsilon_{\mathrm{ijk}}
$$

where $\mathrm{Y}$ is the response, $\mu$ is the overall mean, $t_{i}$ is the treatment effect, $\mathrm{w}_{\mathrm{j}}$ is the time effect, $\mathrm{t} \times \mathrm{w}_{\mathrm{ij}}$ is the interaction between time and treatment, and $\varepsilon_{\mathrm{ijk}}$ is the residual term. The variance-covariance structure of the repeated measures was modeled separately with an appropriate structure fitted using the lowest values of the fit statistics based on the Akaike information criterion. Data on $\mathrm{ADG}$, rumen $\mathrm{pH}$, and VFA profile were analyzed using the MIXED procedure of SAS (SAS 9.4) according to the following model:

$$
\mathrm{Y}=\mu+\mathrm{t}_{\mathrm{i}}+\varepsilon_{\mathrm{ij}}
$$

where $\mathrm{Y}$ is the response, $\mu$ is the overall mean, $t_{i}$ is the treatment effect, and $\varepsilon_{\mathrm{ij}}$ is the residual term. Significance was declared at $P \leq 0.05$ and tendencies were declared at $0.05<P \leq 0.10$. Numbers displayed are least squares means \pm standard error of the mean, unless otherwise indicated. Preplanned contrasts were set up to compare PRE-M versus PRE-S (effect of starter preweaning), PRE-S versus POST-S (effect of weaning), and POST-S versus POST-B (effect of butyrate supplementation).

\section{RESULTS}

Three calves died in the beginning of the study and were removed from the data set. All calves were housed outside in individual hutches for this study. A heat wave starting in wk 6 of the study began to strain calf health in POST-S and POST-B groups. To alleviate heat stress, POST-S and POST-B calves were moved to an indoor facility, still housed separately, on sand, where ambient temperatures more closely resembled previous temperatures outside. Between a choice of imposing heat stress or a relocation, we opted for relocation because the physiological effect of relocation is likely smaller than that of heat stress.

\section{Production Performance}

Between PRE-S and POST-S, starter intake was greater for POST-S at wk 9 than PRE-S at wk 6 (76 \pm

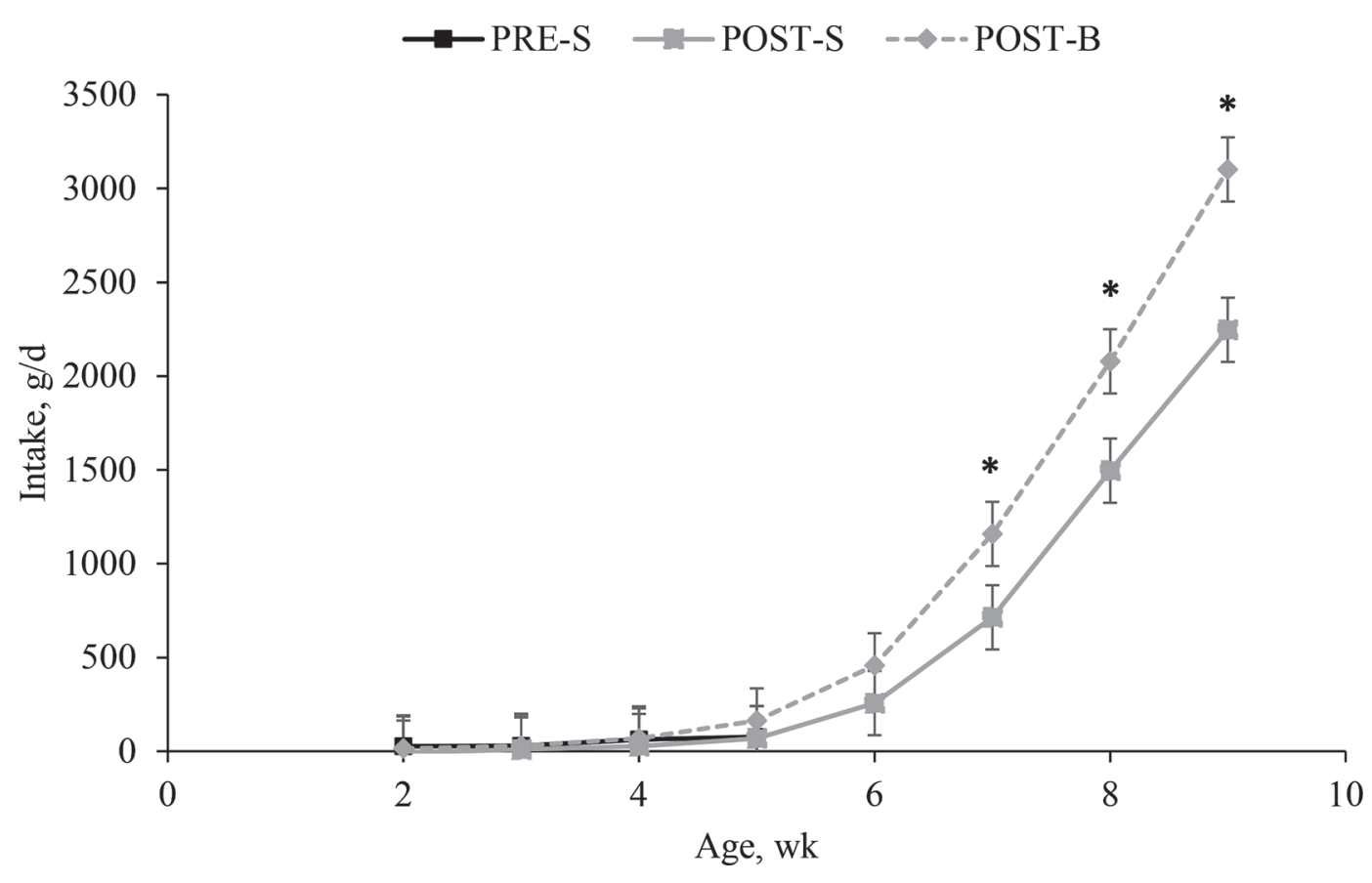

Figure 1. Calf starter intake of dairy calves at $6 \mathrm{wk}$ of age, preweaning, or 9 wk of age, postweaning. PRE-S = milk replacer, starter, hay; slaughtered preweaning $(6 \mathrm{wk} ; \mathrm{n}=9)$; POST-S $=$ milk replacer, starter, hay, no supplementation during wk 7 to 8 ; slaughtered postweaning (9 wk; $\mathrm{n}=8$ ); POST-B = milk replacer, starter, hay, $1 \%$ rumen-protected wt/wt butyrate supplementation during wk 7 to 8 ; slaughtered postweaning $(9 \mathrm{wk} ; \mathrm{n}=8)$. Values are LSM \pm SEM. *Significance $(P<0.05)$ between treatments indicated by an asterisk. 
165 vs. 2,247 $\pm 171 \mathrm{~g} / \mathrm{d}, P<0.01$; Figure 1$)$. Between POST-S and POST-B, starter intake increased in POST-B, starting in wk 7 (706.67 \pm 218.61 vs. $1,151.24$ $\pm 218.61 \mathrm{~g} / \mathrm{d} ; P=0.04)$, wk $8(1,489 \pm 219$ vs. 2,071 $\pm 219 \mathrm{~g} / \mathrm{d} ; P=0.01)$, and postweaning in wk $9(2,247$ \pm 171 vs. $3,102 \pm 171 \mathrm{~g} / \mathrm{d} ; P<0.01)$. Comparing hay intake of PRE-S (wk 6) and POST-S (wk 9), hay intake increased through the weaning transition (144 \pm 95 vs. $784 \pm 98 \mathrm{~g} / \mathrm{d}, P<0.01 ;$ Figure 2). Between POST-S and POST-B, there was no difference in hay intake in wk 7 (507 \pm 98 vs. $442 \pm 98 \mathrm{~g} / \mathrm{d}, P=0.64)$ and wk 8 (689 \pm 98 vs. $633 \pm 102 \mathrm{~g} / \mathrm{d}, P=0.64)$. No difference was observed in ADG between PRE-M and PRE-S $(0.87 \pm 0.04$ vs. $0.82 \pm 0.04 \mathrm{~kg} / \mathrm{d}$, respectively; $P=$ 0.33 ; Figure 3 ) or between PRE-S and POST-S (0.82 \pm 0.04 vs. $0.77 \pm 0.04 \mathrm{~kg} / \mathrm{d}$, respectively; $P=0.37)$, but POST-B had greater ADG than POST-S (0.77 \pm 0.04 vs. $0.92 \pm 0.04 \mathrm{~kg} / \mathrm{d}$, respectively; $P=0.01)$.

Plasma concentrations of glucose were not different between PRE-M and PRE-S, PRE-S and POST-S, and POST-S and POST-B (Figure 4). Plasma BHB concentrations did not differ between PRE-M and PRE-S or PRE-S and POST-S. Differences in plasma BHB were detected between POST-S and POST-B; POST-B had higher $\mathrm{BHB}$ concentrations in wk 7 (1.28 \pm 0.100 vs. $0.918 \pm 0.100 \mathrm{mg} / \mathrm{dL}, P=0.01 ;$ Figure 5$)$ but not wk 8 $(1.58 \pm 0.119$ vs. $1.75 \pm 0.119 \mathrm{mg} / \mathrm{dL}, P=0.31)$.

\section{Rumen Fermentation}

Compared with PRE-M, PRE-S tended to have a higher total VFA concentration $(P=0.08$; Table 1$)$, and had a higher propionate proportion $(P<0.01)$ and a lower A:P ratio $(P<0.01)$. Between PRE-S (wk 6) and POST-S (wk 9), total VFA concentration increased $(P<0.01)$, but VFA proportion did not differ. Comparing POST-S to POST-B, POST-B tended to have a lower total VFA concentration $(P=0.09)$ and had a higher proportion of propionate $(P=0.02)$.

In rumen $\mathrm{pH}$ profile, PRE-M and PRE-S calves had no difference in mean $\mathrm{pH}(P=0.78)$ or duration of $\mathrm{pH}<5.8(P=0.44 ;$ Table 2$)$. Likewise, PRE-S and POST-S showed no difference in mean $\mathrm{pH}(P=0.66)$ or duration of $\mathrm{pH}<5.8(P=0.79)$. Between POST-S, but POST-B calves had a lower mean rumen $\mathrm{pH}$ than POST-S calves $(P=0.05)$ and tended to have a longer duration of $\mathrm{pH}<5.8(P=0.07)$.

\section{DISCUSSION}

\section{Effect of Weaning on Rumen $\mathrm{pH}$}

Weaning is associated with large increases in starter intake, as also seen in this study. Reduction of milk intake is the biggest driver of starter intake (Sweeney

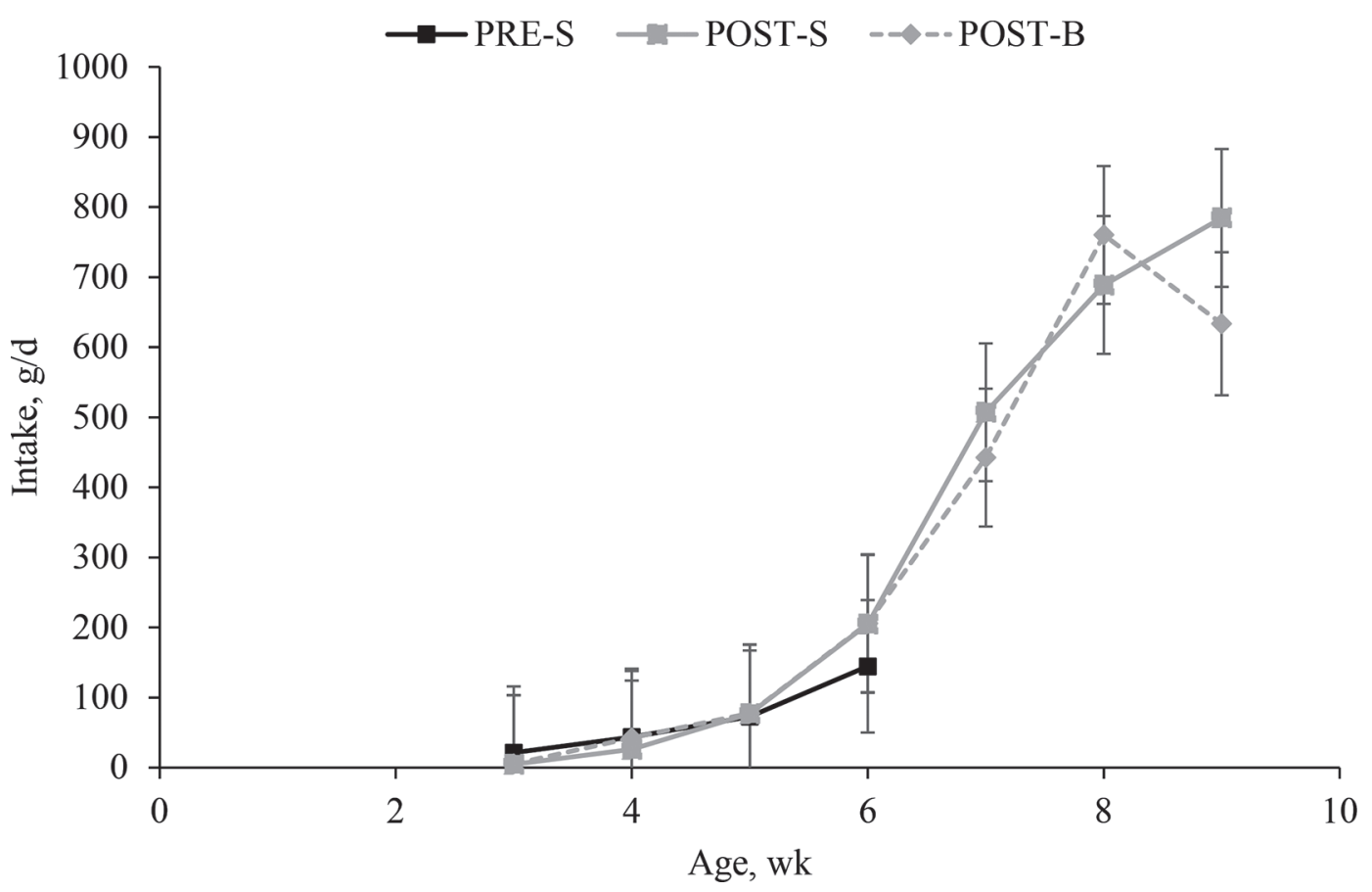

Figure 2. Hay intake of dairy calves at 6 wk of age, preweaning, or 9 wk of age, postweaning. PRE-S = milk replacer, starter, hay; slaughtered preweaning $(6 \mathrm{wk} ; \mathrm{n}=9)$; POST-S $=$ milk replacer, starter, hay, no supplementation during wk 7 to 8 ; slaughtered postweaning $(9$ wk; $\mathrm{n}$ $=8)$; POST-B $=$ milk replacer, starter, hay, $1 \%$ rumen-protected wt/wt butyrate supplementation during wk 7 to 8 ; slaughtered postweaning $(9 \mathrm{wk} ; \mathrm{n}=8)$. Values are LSM \pm SEM. 


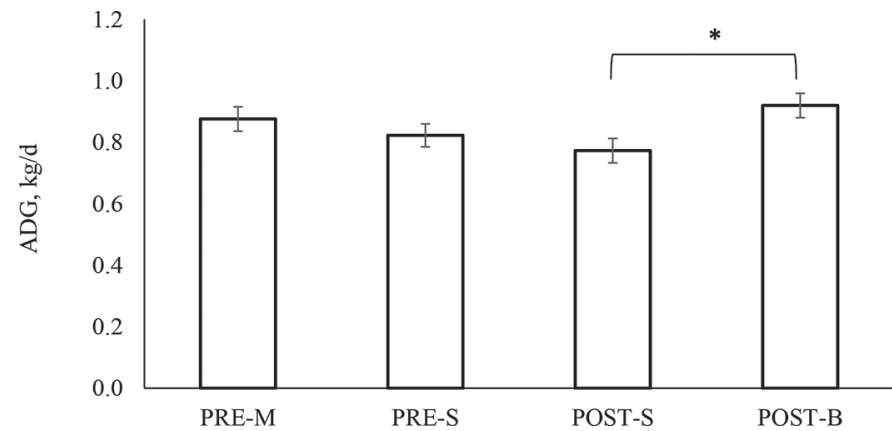

Figure 3. Average daily gain $(\mathrm{kg} / \mathrm{d})$ of dairy calves at 6 wk of age, preweaning, or 9 wk of age, postweaning. PRE-M $=$ milk replacer only; slaughtered preweaning $(6 \mathrm{wk} ; \mathrm{n}=8)$; PRE-S = milk replacer, starter, hay; slaughtered preweaning $(6$ wk; $\mathrm{n}=9$ ); POST-S $=$ milk replacer, starter, hay, no supplementation during wk 7 to 8 ; slaughtered postweaning ( 9 wk; $\mathrm{n}=8$ ): POST-B $=$ milk replacer, starter, hay, $1 \%$ rumen-protected wt/wt butyrate supplementation during wk 7 to 8; slaughtered postweaning ( $9 \mathrm{wk} ; \mathrm{n}=8)$. Values are $\mathrm{LSM} \pm \mathrm{SEM}$ * Significance $(P<0.05)$ between treatments indicated by an asterisk.

et al., 2010). In preweaned calves, rumen $\mathrm{pH}$ is often lower than in mature cows (Khan et al., 2008) with gradual increases in rumen $\mathrm{pH}$ as a calf ages. In studies comparing a milk-only diet and a milk and starter diet, rumen $\mathrm{pH}$ remains the same, despite vast differences in rumen fermentation (Laarman and Oba, 2011; Yohe et al., 2019). Despite the $2,000 \mathrm{~g} / \mathrm{d}$ increase in calf starter intake and a 4-fold increase in total VFA, rumen $\mathrm{pH}$ profile remained similar. Postweaning, however, an 800 $\mathrm{g} / \mathrm{d}$ increase in calf starter intake, as seen in the POST$\mathrm{B}$ treatment, suddenly caused rumen $\mathrm{pH}$ to drop. Why rumen $\mathrm{pH}$ can remain stable despite a $700 \mathrm{~g} / \mathrm{d}$ increase in calf starter intake preweaning (Laarman and Oba, 2011), as well as a $2,000 \mathrm{~g} / \mathrm{d}$ increase during the weaning transition, but suddenly drops with an $800 \mathrm{~g} / \mathrm{d}$ increase postweaning is unclear.

Part of the explanation may lie in the consumption of forage. In studies where rumen $\mathrm{pH}$ is not different between a milk-only diet and a milk and starter diet, hay is typically fed ad libitum (Laarman and Oba, 2011; Terré et al., 2013; Yohe et al., 2019). Typically, hay intake increases with age and appears unrelated to treatment (Khan et al., 2011a; Laarman et al., 2012b), suggesting buffering effects of forage consumption along with metabolic adaptations of the rumen may be enough to maintain rumen $\mathrm{pH}$ (Laarman et al., 2012a; Connor et al., 2013). However, when calf starter DM digestibility is high, or starch readily available, rumen $\mathrm{pH}$ can drop as a result of more rapid fermentation (Khan et al., 2008; Laarman et al., 2012b). Additionally, low forage intake also depresses rumen $\mathrm{pH}$ (Laarman and Oba, 2011; D. E. McCurdy and A. H. Laarman, unpub-

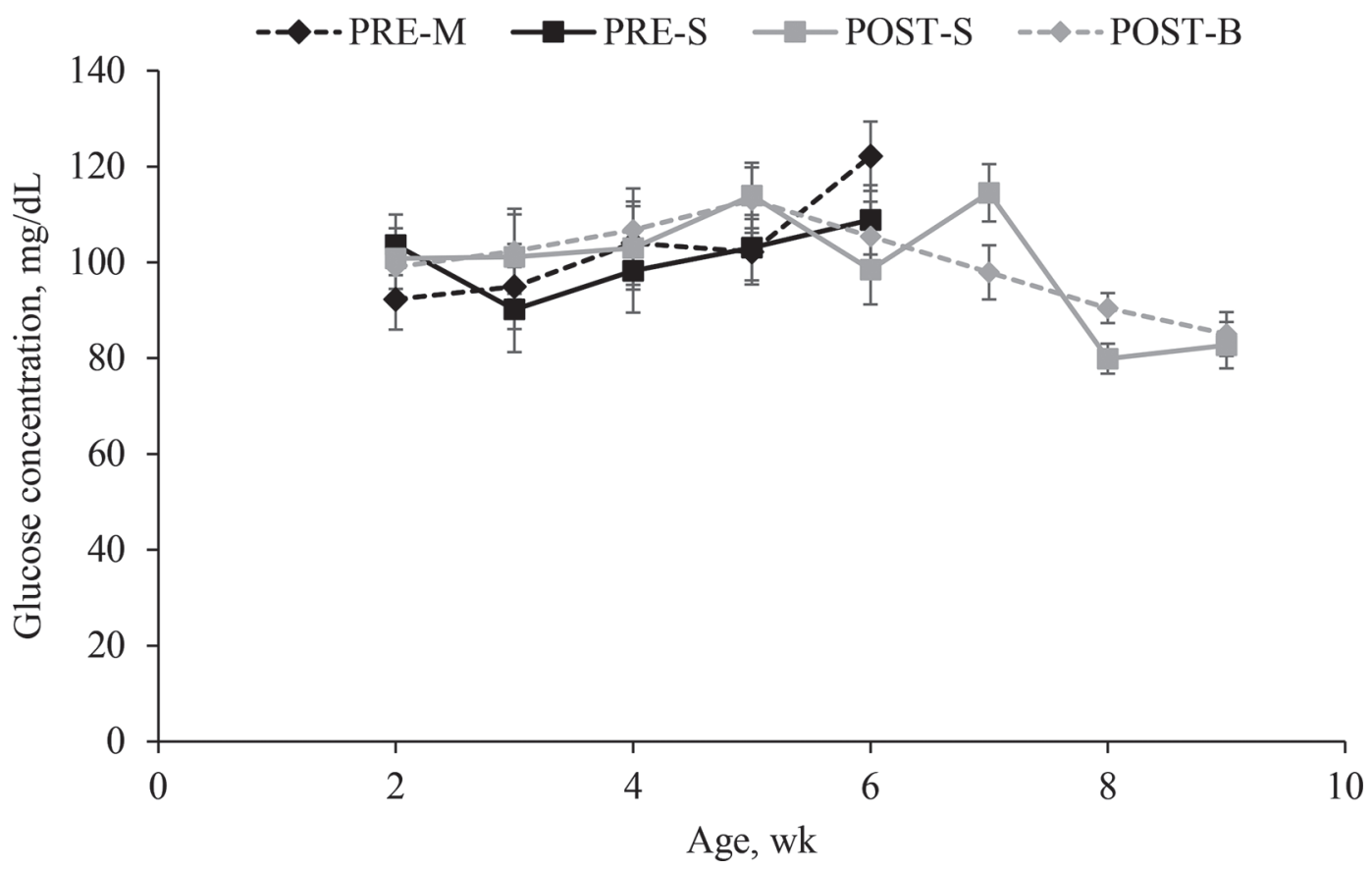

Figure 4. Plasma glucose concentration of dairy calves at 6 wk of age, preweaning, or 9 wk of age, postweaning. PRE-M = milk replacer only; slaughtered preweaning ( $6 \mathrm{wk} ; \mathrm{n}=8)$; PRE-S = milk replacer, starter, hay; slaughtered preweaning $(6 \mathrm{wk} ; \mathrm{n}=9)$; POST-S = milk replacer, starter, hay, no supplementation during wk 7 to 8 ; slaughtered postweaning $(9 \mathrm{wk} ; \mathrm{n}=8)$; POST-B $=$ milk replacer, starter, hay, $1 \%$ rumenprotected wt/wt butyrate supplementation during wk 7 to 8 ; slaughtered postweaning ( $9 \mathrm{wk} ; \mathrm{n}=8)$. Values are LSM \pm SEM. 


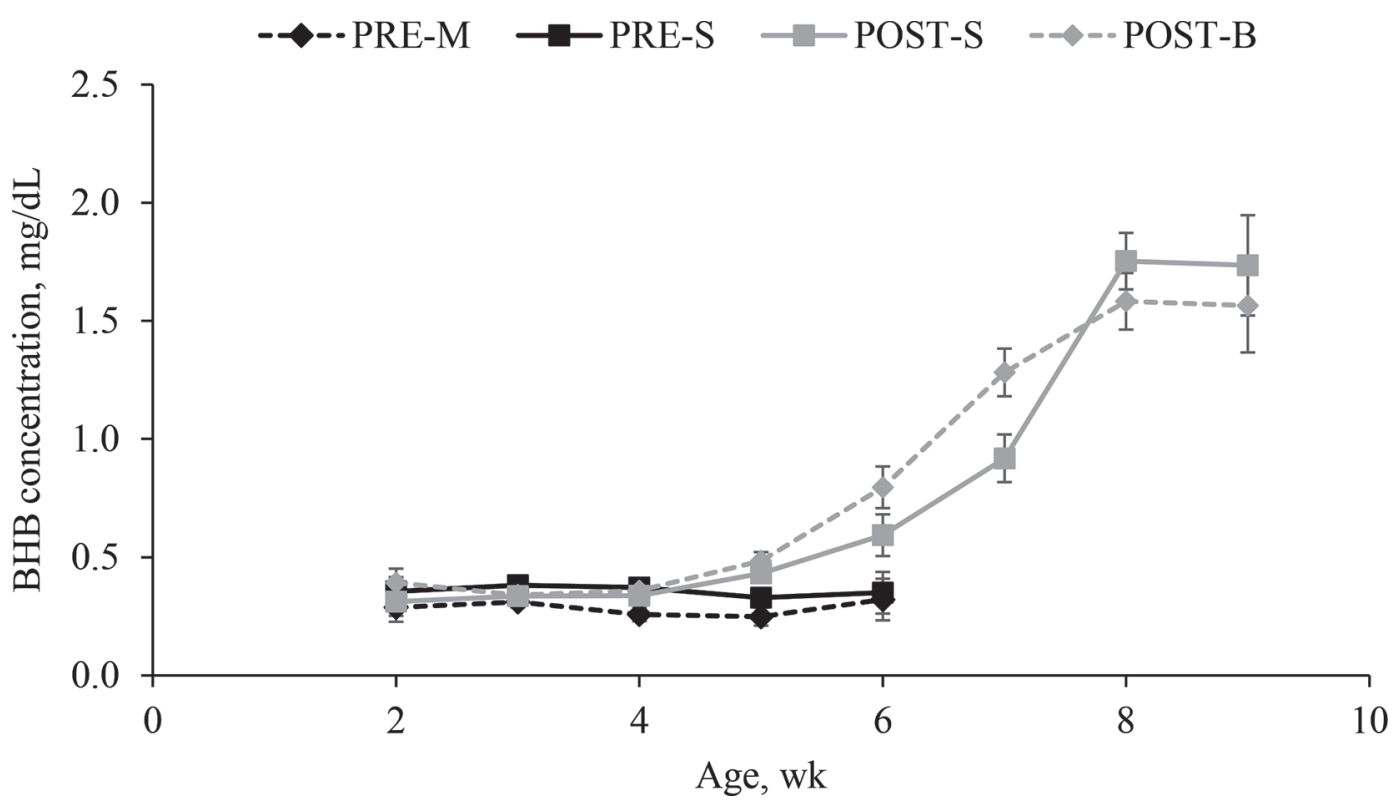

Figure 5. Plasma BHB concentration of dairy calves at 6 wk of age, preweaning, or 9 wk of age, postweaning. PRE-M = milk replacer only; slaughtered preweaning $(6 \mathrm{wk} ; \mathrm{n}=8) ; \mathrm{PRE}-\mathrm{S}=$ milk replacer, starter, hay; slaughtered preweaning $(6 \mathrm{wk} ; \mathrm{n}=9) ; \mathrm{POST}-\mathrm{S}=$ milk replacer, starter, hay, no supplementation during wk 7 to 8 ; slaughtered postweaning (9 wk; $\mathrm{n}=8$ ); POST-B $=$ milk replacer, starter, hay, $1 \%$ rumenprotected wt/wt butyrate supplementation during wk 7 to 8 ; slaughtered postweaning (9 wk; $\mathrm{n}=8)$. Values are LSM \pm SEM.

lished). In all, the ability of the preweaning rumen to adapt to changes in fermentation and acidotic pressures is tremendous, though not limitless. Postweaning, the rumen becomes much more susceptible to changes in fermentability of diets, though the mechanisms explaining these changes require further study.

\section{Butyrate and Solid Feed Intake}

Exogenous butyrate is a popular candidate for improving rumen function because butyrate is known for its bioactivity in multiple tissues (Hamer et al., 2008;
Gorka et al., 2018). In the rumen, butyrate confers multiple protective benefits such as improving tight junctions, epithelial energy mobilization, and VFA absorption capacity (Baldwin et al., 2012; Laarman et al., 2013a). Given the importance of butyrate in promoting rumen development (Sander et al., 1959), butyrate is also a popular candidate for use in preweaning diets. The optimal inclusion rate, enteric target, and timeframe for feeding are currently unclear.

In calves, supplementing starter with rumen-protected butyrate increased calf BW for the first $11 \mathrm{~d}$ and then a second BW increase at weaning (Gorka et

Table 1. Ruminal VFA profile (LSM \pm SEM) of dairy calves at 6 wk of age, preweaning, or 9 wk of age, postweaning ${ }^{1}$

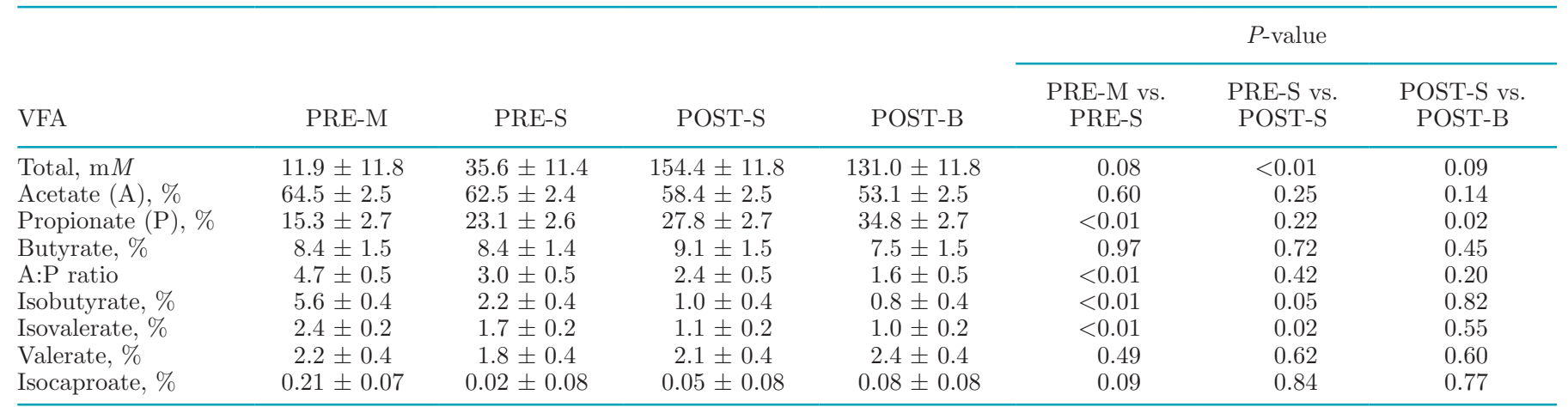

${ }^{1} \mathrm{PRE}-\mathrm{M}=$ milk replacer only; slaughtered preweaning $(6 \mathrm{wk} ; \mathrm{n}=8) ;$ PRE-S = milk replacer, starter, hay; slaughtered preweaning $(6 \mathrm{wk} ; \mathrm{n}=9)$; POST-S $=$ milk replacer, starter, hay, no supplementation during wk 7 to 8 ; slaughtered postweaning $(9$ wk; $\mathrm{n}=8)$; POST-B $=$ milk replacer, starter, hay, $1 \%$ rumen-protected wt/wt butyrate supplementation during wk 7 to 8 ; slaughtered postweaning $(9$ wk; $\mathrm{n}=8)$. 
Table 2. Rumen $\mathrm{pH}$ profile (LSM $\pm \mathrm{SEM}$ ) of the ventral sac of dairy calves at 6 wk of age, preweaning, or 9 wk of age, postweaning ${ }^{1}$

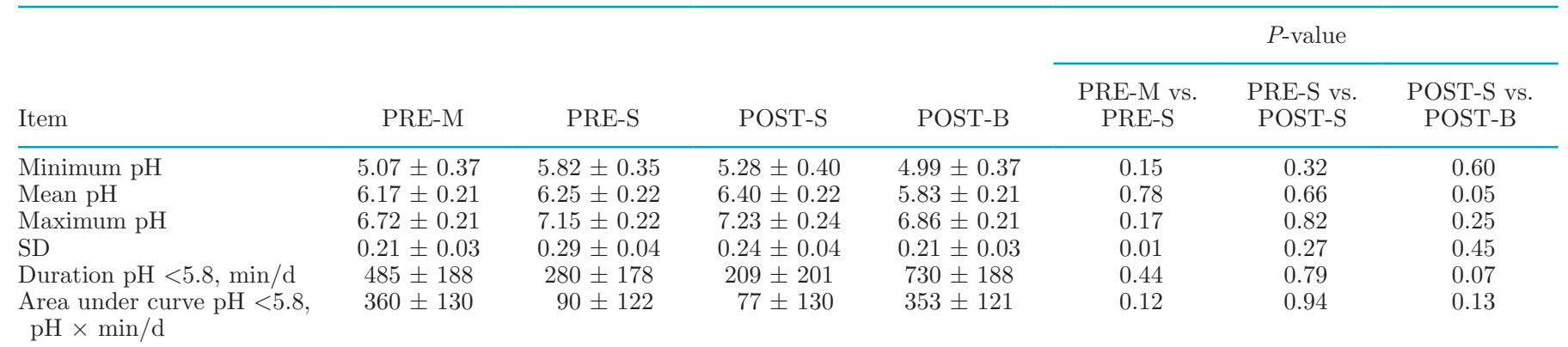

${ }^{1}$ PRE-M = milk replacer only; harvested preweaning $(6 \mathrm{wk} ; \mathrm{n}=8) ;$ PRE-S = milk replacer, starter, hay; harvested preweaning $(6 \mathrm{wk} ; \mathrm{n}=9)$; POST-S $=$ milk replacer, starter, hay, no supplementation during wk 7 to 8 ; harvested postweaning $(9$ wk; $\mathrm{n}=8)$; POST-B $=$ milk replacer, starter, hay, $1 \%$ rumen-protected w/w butyrate supplementation during wk 7 to 8 ; harvested postweaning $(9$ wk; $\mathrm{n}=8)$.

al., 2009), suggesting butyrate may be most effective at select times only. Consequently, this study targeted the weaning transition only to determine if supplemental butyrate could alleviate slowdowns in starter intake and ADG often seen immediately postweaning (Sweeney et al., 2010). Calves in POST-B, which were supplemented with rumen-protected butyrate during wk 7 and 8 only, increased calf starter intake, which was maintained even after butyrate supplementation was removed in wk 9. These results appear to bolster data (Gorka et al., 2009) showing improved weaning performance with rumen-protected butyrate, though the mechanism of action is unclear.

In this study, metrics of rumen development were not measured. In other studies using rumen-protected butyrate, calves fed supplemented starter did have greater rumen papillae (Gorka et al., 2009), despite the butyrate bypassing the rumen. In our study, ruminal butyrate concentrations and plasma BHB concentrations were not different between POST-S and POST-B calves, either weekly (venous flow) or at harvest (arterial/venous mix). Nevertheless, POST-B calves had greater starter intake, suggesting butyrate supplied intestinally may also be beneficial to the young calf; whether rumen-protected butyrate is more beneficial than unprotected butyrate is unclear from these data. Mechanistically, how rumen-protected butyrate could affect the rumen is a suitable target for future research.

\section{SARA and Growth in Young Calves}

Multiple thresholds for SARA exist ranging from 5.5 (Krause and Oetzel, 2006), 5.6 (Gozho et al., 2005), and 5.8 (Aschenbach et al., 2011). In continuous pH measurements, $\mathrm{pH}$ threshold of 5.8 is recommended (Aschenbach et al., 2011). At a $\mathrm{pH}$ range of 5.5 to 6.0, VFA uptake increases (Dirksen et al., 1985; Penner et al., 2009; Laarman et al., 2016), which may explain why
POST-B had increased starter intake but no increase in total VFA concentration. Whether SARA in calves causes spikes in lipopolysaccharides and inflammatory responses seen in adult cows (Emmanuel et al., 2007; Khafipour et al., 2009) is unclear and may explain why lower rumen $\mathrm{pH}$ in POST-B calves did not compromise growth rates.

The effect of SARA on performance appears to be different in cows than in calves. In cows, inducing SARA using high-grain diets decreases DMI (Steele et al., 2011) and is further reduced when unprotected butyrate is added to the rumen (Dionissopoulos et al., 2013). In our study, POST-B calves fed rumenprotected butyrate only during the weaning transition in wk 7 and 8 had increased DMI, lower mean rumen $\mathrm{pH}$, and tended to have lower VFA concentrations postweaning (wk 9). The rumen $\mathrm{pH}$ decrease and tendency for decreased VFA concentrations seen in the POST-B calves is physiologically problematic because low $\mathrm{pH}$ is damaging to the rumen epithelium only when VFA are present (Meissner et al., 2017). More research will need to be done to investigate if the rumen in POST-B calves was differentially developed from POST-S calves, and why calves appear much more able to tolerate lower rumen $\mathrm{pH}$ than cows.

\section{CONCLUSIONS}

The weaning transition does not appear to affect rumen $\mathrm{pH}$, despite calf starter intake increasing by $2000 \mathrm{~g} / \mathrm{d}$, and the ad libitum intake of hay may play a key role in balancing rumen $\mathrm{pH}$ before and during weaning. Supplementing calf starter with rumen-protected butyrate during the weaning transition increased starter intake by $800 \mathrm{~g} / \mathrm{d}$, and the increased intake was maintained even after rumen-protected butyrate supplementation was removed at the end of the $2 \mathrm{wk}$ weaning transition. Postweaning, the observed increase 
in calf starter intake of $800 \mathrm{~g} / \mathrm{d}$ depressed rumen $\mathrm{pH}$, suggesting there are limits to the rumen $\mathrm{pH}$-regulating capacity of young calves. In young calves, which factors regulate rumen $\mathrm{pH}$, and how these factors change during weaning transition remains unclear, warranting further research.

\section{ACKNOWLEDGMENTS}

We acknowledge the University of Idaho Office of Research and Economic Development (Seed Grant FY2016-2017, Moscow, ID), Idaho Agricultural Experiment Station, Department of Animal and Veterinary Science, USDA National Institute for Food and Agriculture (Hatch NC-2040; Washington, DC), and Nutriad Inc. (Hampshire, IL) for funding this research. We also thank Calva Calf Products (Acampo, CA) for their donation, James Allison (USDA, Moscow, ID), and Zac Carlson, Kevin Carnahan, Kristina Davenport, Summer Lowe, Lani Martin, and Jim Vinyard (University of Idaho, Moscow) for their assistance on this study.

\section{REFERENCES}

Aschenbach, J. R., G. B. Penner, F. Stumpff, and G. Gabel. 2011. Role of fermentation acid absorption in the regulation of ruminal $\mathrm{pH}$. J. Anim. Sci. 89:1092-1107. https://doi.org/10.2527/jas.2010-3301.

Baldwin, R. L. V., S. Wu, W. Li, C. Li, B. J. Bequette, and R. W. Li. 2012. Quantification of transcriptome responses of the rumen epithelium to butyrate infusion using RNA-seq technology. Gene Regul. Syst. Bio. 6:67 to 80. https://doi.org/10.4137/GRSB.S9687.

Bergman, E. N. 1990. Energy contributions of VFAs from the gastrointestinal tract in various species. Physiol. Rev. 70:567-590.

Connor, E. E., R. L. Baldwin VI, C. Li, R. W Li, and H. Chung. 2013. Gene expression in bovine rumen epithelium during weaning identifies molecular regulators of rumen development and growth. Funct. Integr. Genomics 13:133-142. https://doi.org/10.1007/ s10142-012-0308-x.

Dionissopoulos, L., A. H. Laarman, O. AlZahal, S. L. Greenwood, M. A. Steele, J. C. Plaizier, J. C. Matthews, and B. W. McBride. 2013. Butyrate-mediated genomic changes involved in non-specific host defenses, matrix remodeling and the immune response in the rumen epithelium of cows afflicted with subacute ruminal acidosis. Am. J. Anim. Vet. Sci. 8:8-27. https://doi.org/10.3844/ajavssp 2013.8.27.

Dirksen, G. U., H. G. Liebich, and E. Mayer. 1985. Adaptive changes of the ruminal mucosa and their functional and clinical significance. Bov. Pract. 20:116-120.

Drackley, J. K. 2008. Calf nutrition from birth to breeding. Vet. Clin. North Am. Food Anim. Pract. 24:55-86. https://doi.org/10.1016/ j.cvfa.2008.01.001.

Emmanuel, D. G. V., K. L. Madsen, T. A. Churchill, S. M. Dunn, and B. N. Ametaj. 2007. Acidosis and lipopolysaccharide from Escherichia coli B:055 cause hyperpermeability of rumen and colon tissues. J. Dairy Sci. 90:5552-5557.

Gorka, P., Z. M. Kowalski, P. Pietrzak, A. Kotunia, W. Jagusiak, and R. Zabielski. 2011. Is rumen development in newborn calves affected by different liquid feeds and small intestine development? J. Dairy Sci. 94:3002-3013.

Gorka, P., Z. M. Kowalski, P. Pietrzak, A. Kotunia, R. Kiljanczyk, J. Flaga, J. J. Holst, P. Guilloteau, and R. Zabielski. 2009. Effect of sodium butyrate supplementation in milk replacer and starter diet on rumen development in calves. J. Physiol. Pharmacol. 60:47-53.
Gorka, P., Z. Kowalski, R. Zabielski, and P. Guilloteau. 2018. Invited review: Use of butyrate to promote gastrointestinal tract development in calves. J. Dairy Sci. 101:4785-4800.

Govil, K., D. S. Yadav, A. K. Patil, S. Nayak, R. P. S. Baghel, P. K. Yadav, C. D. Malapure, and D. Thakur. 2017. Feeding management for early rumen development in calves. J. Entomol. Zool. Stud. 5:1132-1139.

Gozho, G. N., J. C. Plazier, D. O. Krause, A. D. Kennedy, and K. M. Wittenberg. 2005. Subacute ruminal acidosis induces ruminal lipopolysaccharide endotoxin release and triggers an inflammatory response. J. Dairy Sci. 88:1399-1403.

Hall, J. B., A. H. Laarman, M. K. Reynolds, and W. K. Smith. 2018. Performance of backgrounding steers fed diets containing monensin or a lactobacillus fermentation product. Transl. Anim. Sci. 2:S130-S133.

Hamer, H. M., D. Jonkers, K. Venema, S. Vanhoutvin, F. J. Troost, and R. J. Brummer. 2008. Review article: The role of butyrate on colonic function. Aliment. Pharmacol. Ther. 27:104-119. https:// doi.org/10.1111/j.1365-2036.2007.03562.x.

Khafipour, E., D. O. Krause, and J. C. Plaizier. 2009. A grain-based subacute ruminal acidosis challenge causes translocation of lipopolysaccharide and triggers inflammation. J. Dairy Sci. 92:1060 1070. https://doi.org/10.3168/jds.2008-1389.

Khan, M. A., A. Bach, D. M. Weary, and M. A. G. von Keyserlingk. 2016. Invited review: Transitioning from milk to solid feed in dairy heifers. J. Dairy Sci. 99:885-902. https://doi.org/10.3168/jds.2015 $-9975$.

Khan, M. A., H. J. Lee, W. S. Lee, H. S. Kim, S. B. Kim, S. B. Park, K. S. Baek, J. K. Ha, and Y. J. Choi. 2008. Starch source evaluation in calf starter: II. Ruminal parameters, rumen development, nutrient digestibilities, and nitrogen utilization in Holstein calves. J. Dairy Sci. 91:1140-1149. https://doi.org/10.3168/jds.2007-0337.

Khan, M. A., D. M. Weary, and M. A. von Keyserlingk. 2011a. Hay intake improves performance and rumen development of calves fed higher quantities of milk. J. Dairy Sci. 94:3547-3553. https://doi .org/10.3168/jds.2010-3871.

Khan, M. A., D. M. Weary, and M. A. G. von Keyserlingk. 2011 b. Invited review: Effects of milk ration on solid feed intake, weaning, and performance in dairy heifers. J. Dairy Sci. 94:1071-1081. https://doi.org/10.3168/jds.2010-3733.

Krause, K. M., and G. R. Oetzel. 2006. Understanding and preventing subacute ruminal acidosis in dairy herds: A review. Anim. Feed Sci. Technol. 126:215-236. https://doi.org/10.1016/j.anifeedsci .2005.08.004.

Laarman, A. H., L. Dionissopoulos, O. AlZahal, S. L. Greenwood, M. A. Steele, and B. W. McBride. 2013a. Butyrate and subacute ruminal acidosis affect abundance of membrane proteins involved with proton and short chain fatty acid transport in the rumen epithelium of dairy cows. Am. J. Anim. Vet. Sci. 8:220-229. https: //doi.org/10.3844/ajavssp.2013.220.229.

Laarman, A. H., L. Dionissopoulos, O. AlZahal, M. A. Steele, S. L. Greenwood, J. C. Matthews, and B. W. McBride. 2013b. Butyrate supplementation affects mRNA abundance of genes involved in glycolysis, oxidative phosphorylation and lipogenesis in the rumen epithelium of Holstein dairy cows. Am. J. Anim. Vet. Sci. 8:239-245. https://doi.org/10.3844/ajavssp.2013.239.245.

Laarman, A. H., and M. Oba. 2011. Short communication: Effect of calf starter on rumen $\mathrm{pH}$ of Holstein dairy calves at weaning. J. Dairy Sci. 94:5661-5664. https://doi.org/10.3168/jds.2011-4273.

Laarman, A. H., R. A. Pederzolli, K. M. Wood, G. B. Penner, and B. W. McBride. 2016. Effects of subacute ruminal acidosis and low feed intake on short-chain fatty acid transporters and flux pathways in Holstein steers. J. Anim. Sci. 94:3729-3737. https://doi .org/10.2527/jas.2016-0638.

Laarman, A. H., A. L. Ruiz-Sanchez, T. Sugino, L. L. Guan, and M. Oba. 2012a. Effects of feeding a calf starter on molecular adaptations in the ruminal epithelium and liver of Holstein dairy calves. J. Dairy Sci. 95:2585-2594. https://doi.org/10.3168/jds.2011-4788.

Laarman, A. H., T. Sugino, and M. Oba. 2012b. Effects of starch content of calf starter on growth and rumen $\mathrm{pH}$ in Holstein calves 
during the weaning transition. J. Dairy Sci. 95:4478-4487. https:/ /doi.org/10.3168/jds.2011-4822.

Meissner, S., F. Hagen, C. Deiner, D. Günzel, G. Greco, Z. Shen, and J. R. Aschenbach. 2017. Key role of short-chain fatty acids in epithelial barrier failure during ruminal acidosis. J. Dairy Sci. 100:6662-6675. https://doi.org/10.3168/jds.2016-12262.

Penner, G. B., J. R. Aschenbach, G. Gabel, R. Rackwitz, and M. Oba. 2009. Epithelial capacity for apical uptake of short chain fatty acids is a key determinant for intraruminal $\mathrm{pH}$ and the susceptibility to subacute ruminal acidosis in sheep. J. Nutr. 139:1714-1720. https://doi.org/10.3945/jn.109.108506.

Plaizier, J. C., D. O. Krause, G. N. Gozho, and B. W. McBride. 2008. Subacute ruminal acidosis in dairy cows: The physiological causes, incidence and consequences. Vet. J. 176:21-31. https://doi.org/10 $.3168 /$ jds.S0022-0302(07)71569-2.

Quigley, J. D. III, A. P. Smith, and R. N. Heitmann. 1991. Changes in plasma VFAs in response to weaning and feed intake in young calves. J. Dairy Sci. 74:258-263.

Sander, E. G., R. G. Warner, H. N. Harrison, and J. K. Loosli. 1959. The stimulatory effect of sodium butyrate and sodium propionate on the development of rumen mucosa in the young calf. J. Dairy Sci. 42:1600-1605.
Steele, M. A., J. Croom, M. Kahler, O. AlZahal, S. E. Hook, K. Plaizier, and B. W. McBride. 2011. Bovine rumen epithelium undergoes rapid structural adaptations during grain-induced subacute ruminal acidosis. Am. J. Physiol. Regul. Integr. Comp. Physiol. 300:R1515-R1523. https://doi.org/10.1152/ajpregu.00120.2010.

Sweeney, B. C., J. Rushen, D. M. Weary, and A. M. de Passillé. 2010. Duration of weaning, starter intake, and weight gain of dairy calves fed large amounts of milk. J. Dairy Sci. 93:148-152. https:/ /doi.org/10.3168/jds.2009-2427.

Terré, M., E. Pedrals, A. Dalmau, and A. Bach. 2013. What do preweaned and weaned calves need in the diet: A high fiber content or a forage source? J. Dairy Sci. 96:5217-5225. https://doi.org/10 $.3168 /$ jds.2012-6304.

Weary, D. M., J. Jasper, and M. J. Hotzel. 2009. Understanding weaning distress. Appl. Anim. Behav. Sci. 110:24-41.

Yohe, T. T., H. Schramm, R. R. White, M. D. Hanigan, C. L. M. Parsons, H. L. M. Tucker, B. D. Enger, N. R. Hardy, and K. M. Daniels. 2019. Form of calf diet and the rumen. II: Impact on volatile fatty acid absorption. J. Dairy Sci. 102:8502-8512. https://doi .org/10.3168/jds.2019-16450. 